\title{
Bożogrobca Stanisław z Łowicza \\ i jego księgozbiór
}

$\mathbb{B}$ ożogrobcy, zwani stróżami Grobu Chrystusowego (Canonici Regulares Custodes Sanctissimi Sepulchri Hierosolymitani), lub popularnie miechowitami to zakon o silnych tradycjach intelektualnych, a jednocześnie jedno $\mathrm{z}$ najbogatszych $\mathrm{w}$ Polsce zgromadzeń kościelnych.

W historiografii polskiej, jak dotąd, brakuje szczegółowego, naukowego opracowania dziejów tej wspólnoty zakonnej. Najwięcej informacji zawiera monumentalne - oparte na materiałach źródłowych obecnie utraconych - dzieło historyka i kronikarza miechowitów Samuela Nakielskiego wydane w 1634 roku. ${ }^{1} \mathrm{Z}$ nowszej literatury warto wymienić obszerny artykuł Mieczysława Tobiasza z 1963 roku ${ }^{2}$ oraz monografię Miechowa napisaną przez Zbigniewa Pęckowskiego. ${ }^{3}$ Pozostałe opracowania przynoszą jedynie informacje podstawowe lub w sposób fragmentaryczny omawiaja niektóre zagadnienia $\mathrm{z}$ polskich dziejów tego zakonu.

Początki ich działalności związane sa ze zdobyciem Jerozolimy w roku 1099 przez rycerstwo europejskie. Powstała wówczas konieczność powołania zakonu rycerskiego, którego misją byłaby obrona Grobu Chrystusowego przed niewiernymi oraz opieka nad pielgrzymami. Przez pierwsze lata był to zakon o charakterze świeckim, dopiero otrzymawszy od patriarchy jerozolimskiego Arnulfa z Rohez w roku 1114 regułę św. Augustyna, stali się wspólnotą klasztorną, jako jeden z odłamów kanoników regularnych. Zakonnicy ci nosili czarne habity z naszytym podwójnym czerwonym krzyżem, który jednocześnie był godłem zgromadzenia.

Stróże Grobu Chrystusowego przybyli do Polski w 1163 roku. Ich polskim fundatorem był potężny możnowładca małopolski Jaksa z Miechowa, który w roku 1162 udał się na pielgrzymkę do Ziemi Świętej i sprowadził stamtąd pierwszego kanonika zwanego Marcinem Gallem (zm. 1198).

Jako swoje uposażenie bożogrobcy otrzymali od fundatora trzy wsie, między innymi Miechów. ${ }^{7}$ Zakonnicy systematycznie powiększali swój majątek poprzez racjonalną i nowoczesną gospodarkę, dalsze donacje, jak i liczne przywileje królewskie. ${ }^{8} \mathrm{~W}$ połowie XV wieku byli już właścicielami dwóch miast (Miechów i Skaryszów) i czterdziestu ośmiu wsi.

7. Badan Nad Polskim Ksiçgodiorami I listorycznymi.

T. 17, Warszawa 1996, 
Przez wieki wywierali decydujący wpływ na rozwój gospodarczy i kulturalny Miechowa (będącego ich siedziba generalna) oraz całego regionu. To właśnie od swojej głównej rezydencji przyjęli polską nazwę miechowitów.

Podzieleni byli na cztery, ściśle ze sobą związane prowincje: małopolską wraz ze Spiszem, wielkopolska, mazowiecką i ruską (zwaną też przemyska). W roku 1574 - oprócz miechowskiej - zarządzali 25 parafiami. ${ }^{9}$ Najwyższe stanowisko $\mathrm{w}$ wewnętrznej organizacji polskiej prowincji zajmował prepozyt kościoła miechowskiego, nazywany później generałem i opatem miechowskim. Jego wybór był początkowo zatwierdzany przez patriarchę jerozolimskiego, a od XV wieku jedynie przez biskupa krakowskiego. Drugie stanowisko w klasztorze zajmował kustosz. Według uchwały przyjętej w 1470 roku musiał nim być najzdolniejszy z braci zakonnej.

Zgodnie z regułą bożogrobcy zajmowali się duszpaterstwem, szerzeniem w Polsce i krajach sąsiednich kultu Grobu św. i Zmartwychwstania oraz szpitalnictwem. Do ich obowiazków należało również prowadzenie szkół parafialnych i opieka nad uboga młodzieżą. Szczególnie znana i prowadzona na wysokim poziomie była szkoła miechowska, dla której nowy, murowany budynek powstał dzięki funduszowi przekazanemu przez jednego z jej absolwentów, Macieja z Miechowa (ok. 14571523). ${ }^{11}$ Mury tej szkoły opuściło wielu wybitnych uczniów, a wśród nich wspomniany wyżej autor (hronica Polonorum, rektor Akademii Krakowskiej Daniel Sigonius (zm. 1638) i dziekan katedry lwowskiej Jan Baranowski (zm. 1639).

Szczyt rozwoju zakonu nastapił w początkach XVI wieku, w znacznej mierze dzięki działalności proboszcza generalnego Tomasza Bylicy z Olkusza (1508-1542). Przywiązywał on dużą wagę do wykształcenia, zreformował istniejące od początków XV wieku w Miechowie studium filozoficzno-teologiczne, a w 1533 roku ustanowił specjalny fundusz oświatowy w wysokości 1200 złotych. Roczne odsetki z tego funduszu przeznaczano na utrzymanie w Bursie Jagiellońskiej dwóch zakonników oraz opłacenie ich nauki w Akademii Krakowskiej. ${ }^{13}$ Bożogrobcy przez lata byli blisko zwiazzani z Akademia Krakowską. Wielu zakonników studiowało i zdobywało kolejne stopnie naukowe właśnie w tej uczelni. Dopiero w początkach XVII wieku utworzono fundację umożliwiająca miechowitom kontynuowanie studiów teologicznych w Rzymie. ${ }^{14}$ 
Przy kilku klasztorach prowadzony był nowicjat i studium filozoficzno-teologiczne dla kleryków. Opiekę sprawowali kanonicy z tytułem profesora teologii i filozofii.

Troska o rozwój intelektualny członków i kandydatów do zakonu powoduje wzrost zbiorów bibliotecznych. Dbałość o bibliotekę, prowadzenie ksiag inwentarzowych, kupowanie i wypożyczanie książek należało do obowiązków konserwatora. ${ }^{15}$ Istnienie biblioteki w Miechowie udokumentowane jest źródłowo od końca XIV wieku.

Przez kilka wieków bożogrobcy zdołali zgromadzić tam jedną z najbogatszych w Polsce książnic klasztornych. W 1762 roku liczyła ona około 9 tysięcy książek i kilkaset rękopisów. ${ }^{16}$ Pomimo dużych strat spowodowanych przez pożary w 1379, 1506, 1732 i 1745 roku, Samuel Bogumił Linde po kasacie zakonu w 1819 roku, zdołał wybrać 4644 tomów i przesłać je do tworzonej przez niego Biblioteki Publicznej przy Uniwersytecie Warszawskim. Część z nich przeszła następnie do szkół wojewódzkich i seminariów duchownych. ${ }^{17} \mathrm{~W}$ Miechowie, według informacji ks. Wiśniewskiego, pozostało jedynie kilkaset książek.

Obecnie księgozbiór miechowski w istotnych ilościach przechowywany jest w czterech książnicach. Biblioteka Uniwersytetu Warszawskiego, jako bezpośrednia spadkobierczyni księgozbioru i tragicznych losów Biblioteki Publicznej przy Uniwersytecie Warszawskim, posiada obecnie zbiór najbogatszy. Zasób szesnastowieczny liczy ponad 500 woluminów. $Z$ wieku siedemnastego dotychczas opracowano proweniencyjnie ponad 135 egzemplarzy. ${ }^{19} \mathrm{Z}$ licznych i ważnych inkunabułów, o których pisał Linde, ${ }^{20}$ zachował się w BUW niestety tylko jeden. Drugi dość liczny zapewne zbiór, znajduje się w Bibliotece Seminarium Archidiecezjalnego w Warszawie. Niestety trudno określić jego wielkość, ponieważ $w$ bibliotece nie prowadzi się systematycznych badań proweniencyjnych. ${ }^{21} \mathrm{~W}$ Miechowie, w Rzymsko-Katolickiej Parafii Grobu Bożego, obecnie przechowywanych jest ponad 520 książek z dawnego księgozbioru miechowitów. ${ }^{22} \mathrm{Z}$ bibliotek warszawskich należałoby ponadto wymienić Bibliotekę Narodowa, gdzie w latach dwudziestych skomasowano wszystkie rewindykaty z Petersburga. Mimo strat wojennych nadal znajduje się tam 5 średniowiecznych rękopisów a zapewne i inne druki, o których dzisiaj nie możemy nic powiedzieć $z$ powodu braku danych. W Bibliotece Seminarium Duchownego w Kielcach przechowuje się iluminowany rękopis Antiphonarium ecclesiae Miechoviensis z 1580 roku, a być może i kilka druków. 
Biblioteka miechowska powstawała w dużej mierze dzięki darowiznom różnych znakomitości życia publicznego jak np. wspomnianego wyżej Macieja z Miechowa. ${ }^{24}$ Innym darczyńca był Jan Baranowski, który w testamencie z 1639 roku legował swój księgozbiór bożogrobcom. $^{25}$

Jednakże zdecydowanie najpełniej, biblioteka powiększała się dzięki księgom po zmarłych członkach wspólnoty, które po ich śmierci były do niej wcielane. Wśród byłych właścicieli dzieł znajdujemy takie nazwiska jak: Walenty ze Skaryszowa, proboszcz w Chełmcach (XVI w.), Łukasz Słończewski z Wyszogrodu (ok. 1488-1563), biskup kamieniecki, Andrzej Batory (1563-1599), opat miechowski, Tyburcjusz Jaskłowski (zm. 1629), prepozytor kościoła św. Jana w Gnieźnie, ${ }^{26}$ Tomasz Ligocki, od 1630 r. prepozyt wyszogrodzki, Samuel Nakielski (1584-1652), historyk, archiwista i bibliotekarz w Miechowie, Florian Buydecki (zm. 1783), generał miechowski, i wielu innych.

Obecnie zajmiemy się ocalałym fragmentem zbioru dawnych ksiag należących ongiś do Stanisława z Łowicza zwanego Beda vel Bieda, a także Venatorius.

Badanie życia i działalności Stanisława z Łowicza niesie z sobą zasadnicze trudności. W poczatkach XVI wieku był to bowiem trzeci już Stanisław z Łowicza, aktywnie działający w Krakowie i jego okolicach, ${ }^{27}$ o czym wspomina Władysław Wisłocki w swojej historii Uniwersytetu Jagiellońskiego. ${ }^{28}$ Niektórzy $\mathrm{z}$ autorów, zwłaszcza opracowań starszych, łączą niestety te osoby powodując niemałe zamieszanie. ${ }^{29}$

Krótkie wzmianki o naszym bożogrobcy zamieścili XIX-wieczni historycy Józef Gacki ${ }^{30}$ i ksiądz Piotr Pękalski. ${ }^{31}$ Natomiast ksiądz Marian Buliński mylnie nazwał go Tomaszem. ${ }^{32}$ Jednakże nie wnieśli oni wiele nowego ponad te informacje, które podał już Nakielski w Miechovii.

Dopiero biogram autorstwa Henryka Barycza opublikowany w drugim tomie Polskiego Slownika Biograficznego nie tylko systematyzował te wiadomości, ale i poszerzył je o lata studiów na Akademii Krakowskiej. ${ }^{33}$ Treść wspomnianego biogramu powtórzył w Slowniku polskich teologów katolickich ks. Hieronim E. Wyczawski. ${ }^{34}$ Najobszerniejsza dotychczas notę biograficzną opracował Zbigniew Pęckowski w nowej edycji Encyklopedii Katolickiej, ${ }^{35}$ wykorzystawszy w pełni wszelkie wzmianki o Stanisławie zawarte w Miechovii Nakielskiego.

Śledząc informacje o Stanisławie z Łowicza można zauważyć istotne różnice zdań związane z jego przydomkami czy nazwiskiem. Wiek XVI, a szczególnie jego poczatki to okres stopniowego wykształcania się na- 
zwisk. Najczęściej składało się ono wówczas z imienia i nazwy miejscowości $z$ jakiej dana osoba pochodziła. Sam Stanisław, jak to widzimy na podpisie obrazu z Wrocieryża (o którym jeszcze będzie mowa), czy w niektórych zapisach proweniencyjnych, używał przydomka "Venatorius", co można tłumaczyć jako łowiec, lowczy. Jest to zapewne próba zlatynizowania nazwy rodzinnego miasta Łowicz. W okresie Odrodzenia znane były przypadki przybierania łacińskich przydomków, również w najbliższym Stanisławowi otoczeniu. Jego przyjaciel, miechowita Łukasz Słończewski miał przydomek Altipolita, a Łukasz z Orłowa, z którym w połowie XVI wieku wspólnie bronili rozpraw doktorskich, zwany był Akwilinus. Poprzez swoich współczesnych nasz Stanisław nazywany był też Beda. Taką formę przydomka znajdujemy zarówno na zapisie proweniencyjnym w książce (por. poz. 2) jak i w liście prymasa Dzierzgowskiego z 1557 roku, cytowanym przez Nakielskiego. ${ }^{36}$ Józef Gacki w połowie XIX wieku napisal: "Stanislaw lowiczanin byl wówczas druga ozdoba zakonu. Maz gruntownej nauki i stad zwany Beda..." etc. ${ }^{37}$ Podobnych określeń użył wcześniej Nakielski pisząc o Stanisławie „vir eruditus et eloquens". ${ }^{38}$ Natomiast Antoni Karbowiak w krótkiej wzmiance o Stanisławie sugerowal, że to Nakielski omyłkowo z przydomka Bieda zrobił Beda i co za tym idzie, mylnie wydedukował, że Stanisław był tak nazywany z powodu swej wyjątkowej erudycji. ${ }^{39} \mathrm{Nie}-$ odparcie zatem nasuwa się porównanie ze średniowiecznym sławnym benedyktynem, świętym zwanym Beda Venerabilis (ok. 673-735). Zainteresowanie historiografia (Stanisław prowadził kronike klasztoru miechowskiego), a zwłaszcza szczególny kult dla Najświętszej Marii Panny, być może stanowiły przyczynę, że traktat Stanisława bożogrobcy o Niepokalanym Poczęciu NMP wielu bibliografów przypisało Czcigodnemu Bedzie (będzie o tym jeszcze mowa później).

We współczesnej historiografii nadal istnieje zamieszanie zwiazzane $\mathrm{z}$ formą nazwiska naszego miechowity. Wielu historyków zapisuje go pod polskim przydomkiem "Bieda", transponując $w$ ten sposób łacińską formę Beda. ${ }^{40}$ Spotykamy również takie formy jak: [z] Łowicza Stanisław (Bieda), [z] Łowicza Stanisław II czy Bieda (Beda) Stanisław $z$ Łowicza. W tym stanie rzeczy uważam, że należałoby wprowadzić ujednoliconą formę nazwiska $\mathrm{i}$ imienia w postaci: Stanisław z Łowicza (Beda, Bieda).

Niewiele zachowało się wiadomości o życiu tego uczonego zakonnika bowiem zniszczeniu uległa większość źródeł archiwalnych. W poczatkach XVI wieku Lowicz by! niemal doszczętnie spustoszony przez 
pożary w latach 1515,1525 i $1526 .{ }^{41}$ Ogień również trawił kilkakrotnie archiwum klasztorne w Miechowie.

Stanisław urodził się w początkach XVI stulecia, w Łowiczu lub jego bliskich okolicach. Wiemy, że matką jego była Helena z Łęczkowic (?), zmarła w 1548 roku. Otóż w kościele parafialnym we Wrocieryżu (powiat pińczowski), gdzie Stanisław był proboszczem, zachował się obraz wotywny namalowany przez nieznanego twórcę dla upamiętnienia jej śmierci. Obraz olejny namalowany na desce przedstawia Jezusa Ukrzyżowanego, z klęczącymi postaciami adorujących: Stanisława i jego matki Heleny. $Z$ prawej strony postaci matki namalowano herb Pilawa na tarczy, co wskazywałoby na to, że pochodziła ona $z$ rodu szlacheckiego pieczętującego się tym godłem. Na pochodzenie szlacheckie wskazuje również strój niewiasty, chociaż mógł być to także ubiór zakonnicy. Być może matka Stanisława pod koniec życia wstapiła do któregoś ze zgromadzeń zakonnych. Pod obrazem widnieje napis: „Nobili et Honestae Matronae Helenae A Lęczkowicze Parenti Suae Dilectae Mortus M/agister/ Stanislaus Venatorius Coenobita Miechovien/sis/ hinque Ecclesiae Parochus Ergo Amoris posuit Anno Dom/inil MIDXLVIII". Przy postaci Stanisława artysta namalował natomiast godło bożogrobców przedstawiające podwójnie łamany krzyż. ${ }^{42}$ Brak niestety jakichkolwiek informacji o ojcu Stanisława. Prawdopodobnie był on pochodzenia mieszczańskiego

Nauki elementarne pobierał Stanisław zapewne w łowickiej szkole kolegiackiej. W owym czasie była ona jedną z kolonii Akademii Krakowskiej i stała na bardzo wysokim poziomie. ${ }^{43}$ Wielu Łowiczan kontynuowało naukę na Uniwersytecie Jagiellońskim i zdobywało tam stopnie naukowe.

Łowicz od początków swojego istnienia (pierwsza wzmianka w źródłach pochodzi z 1136 r.) był własnością arcybiskupów gnieźnieńskich. Do końca osiemnastego wieku wywierali oni istotny wpływ na rozwój gospodarczy i kulturalny miasta. Zaznaczyło się to zwłaszcza w początkach XVI wieku, kiedy Łowicz stał się faktyczną stolicą arcybiskupstwa gnieźnieńskiego. Wokół dworu arcybiskupów gromadzili się wybitni ludzie nauki i kultury, co nie pozostawało bez wpływu na mieszkańców Łowicza i okolic. Dzięki protekcji kolejnych prymasów kupcy łowiccy otrzymywali liczne korzystne przywileje królewskie. Szczególnie silnie Łowicz związał się z położonym nad Wisłą (u ujścia Bzury do Wisły) Wyszogrodem, gdzie Łowiczanie mieli własne składy zbożowe. ${ }^{44}$ To właśnie wyszogrodzki kościól parafialny pod wezwaniem świętej 
Trójcy już od 1320 roku oddany był pod opiekę bożogrobcom przez księcia płockiego Wacława. ${ }^{45}$ Być może rodzina naszego bożogrobcy byłą związana $\mathrm{z}$ kupiectwem, a kontakty zawodowe $\mathrm{z}$ Wyszogrodem zainspirowały młodego łowiczanina do wstapienia do zgromadzenia miechowitów.

Stanisława $z$ Łowicza po raz pierwszy wpisano do albumu studentów Akademii Krakowskiej w 1524 roku, jako „Beda Slanislai de Lovycz dioc. (Ineznensis". Zapłacił wówczas jeden grosz. ${ }^{46}$ Studia kontynuowal w latach trzydziestych, dzięki fundacji utworzonej przez opata miechowskiego Tomasza z Olkusza. ${ }^{47}$ W 1533 roku, za dekanatu Stanisława z Krakowa został promowany do stopnia bakałarza nauk wyzwolonych. ${ }^{48}$ Dwa lata później, w okresie dekanatu magistra teologii Mikołaja z Szadka, otrzymał tytuł magistra. ${ }^{49}$ Przez pewien czas pozostał w Krakowie i wykładał przez trzy półrocza - do jesieni 1536 roku - na Wydziale Teologicznym jako extraneus non de facultate. ${ }^{50}$ Następnie powrócił do Miechowa, gdzie $w$ istniejącym przy klasztorze kolegium filozoficzno-teologicznym wykladał Pismo Swięte. Nasz Stanisław prowadził także kronikę klasztorną, ${ }^{51}$ bowiem Nakielski powołuje się na pisany przez niego diariusz M.S.Codex (onventualis, antiqua diaria. Pandecta memoriae fratrum. ${ }^{52}$ Ponadto poświęcił się działalności pisarskiej i kaznodziejskiej.

W 1538 roku w krakowskiej drukarni Heleny Unglerowej ukazała się jego pierwsza książka zawierająca traktat o Niepokalnym Poczęciu Najświętszej Marii Panny. ${ }^{53}$ Traktat uzupełniono trzema kazaniami, wygłoszonymi uprzednio po polsku w kościele Najświętszej Marii Panny w Krakowie. Obejmuje on ponadto reguły życia religijnego i monastycznego oraz suplikacje do Matki Boskiej Niepokalanego Poczęcia. Pracę tę Stanisław dedykował prepozytowi generalnemu miechowitów Tomaszowi z Olkusza, swojemu dobroczyńcy i godnemu uwielbienia mecenasowi wszystkich studiujących - jak go nazywa. Opis tej książi został poczatkowo przez Karola Estreichera podany pod hasłem: Beda Venerabilis. ${ }^{54}$ Jednak w tomie 21 Bihliografii Polskiej, odnajdujemy ponownie toż dziełko przypisane prawidłowo bożogrobcy Stanisławowi z Łowicza. ${ }^{55}$ Wszakże za pierwotnym mylnym ustaleniem estreicherowskim poszli niektórzy bibliografowie i nadal traktat Stanisława $\mathrm{z}$ Łowicza przypisywany bywa Bedzie Czcigodnemu. ${ }^{56}$ Pod takim hasłem zamieściła go również międzynarodowa bibliografia Index Aureliensis.

Ten traktat mariologiczny ponownie wydano w 1747 roku, staraniem doktora teologii Jakuba Pawła Radlińskiego, prepozyta generalnego 
w Miechowie. W przedmowie wydawca napisał, że po wielkim pożarze klasztoru miechowskiego w 1745 roku, nie zachował się ani jeden wolumin oryginalnego wydania. Po wielu poszukiwaniach, jedyny egzemplarz odnalazł się w Bibliotece Załuskich i on posłużył do przedrukowania. ${ }^{58}$ Wszakże nie była to ścisła informacja, bowiem obecnie katalog centralny poloników XVI w. Biblioteki Narodowej notuje sześć egzemplarzy w kraju, a w samej BN znajdują się aż 3 woluminy wydania z $1538 \mathrm{r}$.

W ciagu następnych lat Stanisław opublikował jeszcze dwa, nienotowane obecnie w katalogach wydania: ponownie Regulae vitae monasti$c a e^{59}$ oraz pieśni nabożne do Matki Boskiej De Maria Virgine Deipara, dedykowane Leonardowi Słończewskiemu, miechowicie i kaznodziei kościoła katedralnego w Krakowie. ${ }^{60}$ Napisał ponadto - prawdopodobnie pozostawiony jedynie w rękopisie - życiorys swego dobroczyńcy Tomasza z Olkusza.

W okresie późniejszym (1539-41) był przełożonym bożogrobców przy kościele parafialnym $w$ Łęgonicach dekanatu rawskiego, a następnie został proboszczem we Wrocieryżu koło Pińczowa w dekanacie jędrzejowskim (1542-1554). Kościół we Wrocieryżu nie tylko wyposażył w obraz wotywny swojej matki, o czym już była mowa, ale go znacznie powiększył i odnowił. Upiększoną budowlę konsekrował wspomniany wyżej Łukasz Słończewski, wówczas już biskup kamieniecki.

Jako proboszcz wrocieryski Stanisław sprawował jednocześnie funkcję kaznodziei w kościele Najświętszej Marii Panny w Krakowie. W crasie wypetniania tych obowiąków, w pracach parafialmych, jak było wówczas w zwyczaju, zastępował go ksiądz Stanisław Polak (Poliak), bakałarz nauk wyzwolonych. ${ }^{63}$ Miechowici często zostawali kaznodziejami. $\mathrm{Na}$ takie stanowiska wybierano jednak osoby wysoko wykształcone w zakresie teologii i filozofii. Najsłynniejszym kaznodzieją wywodzącym się z tej wspólnoty był przyjaciel Stanisława, Leonard z Wyszogrodu (Słończewski). ${ }^{64}$ Stanisław był popularnym mówcą. Leonard, dzięki poparciu królowej Bony otrzymawszy stanowisko biskupa kamienieckiego, wystapił 1 października 1546 roku do kapituły krakowskiej z prośba o mianowanie na swoje miejsce jako kaznodziei zwyczajnego w katedrze, Stanisława z Łowicza. Jednakże nie otrzymał Stanisław tego stanowiska, bowiem kanonicy mieli własnego kandydata, Łukasza z Orłowa. ${ }^{65}$

W 1553 roku, pod opieka znanego i wpływowego teologa Jakuba z Kleparza, uzyskat tytul doktora teologii. Uroczysta promocja odbyła sie 
4 lutego, w kościele św. Anny, wspólnie z dwoma wybitnymi teologami Benedyktem z Koźmina i Łukaszem z Orłowa. Swoja obecnościa uświetnili ją król Zygmunt August i biskup krakowski Andrzej Zebrzydowski. ${ }^{66}$ Przy tej okazji król po raz pierwszy zwiedził Bibliotekę Jagiellońską. Następnego dnia biskup Zebrzydowski wyprawił ucztę na cześć świeżo promowanych, $\mathrm{z}$ udziałem króla i innych wybitnych przedstawicieli świata duchownego i świeckiego.

W roku następnym, po śmierci Marcina z Wrześni, aktem wydanym 8 października prymas Mikołaj Dzierzgowski powierzył Stanisławowi stanowisko proboszcza kościoła św. Jana na gnieźnieńskim przedmieściu. Klasztor w Gnieźnie był drugim w kolejności znaczenia po siedzibie generalnej. ${ }^{68}$ Zwykle posyłano tam najzdolniejszych kanoników. Stanisław Bieda $z$ Łowicza pozostał w Gnieźnie aż do śmierci w 1574 roku. ${ }^{69}$

Stanisław w ciagu swego życia był blisko związany z wieloma wybitnymi osobistościami Kościoła katolickiego. Pełnił funkcję kaznodziei prymasa Mikołaja Dzierzgowskiego. $\mathrm{Na}$ jego prośbę zawartą w liście z 7 sierpnia 1557 roku, Stanisław wygłosił mowę na synodzie piotrkowskim. Tekst tego przemówienia, o czym wspomina Nakielski, przechowywano $\mathrm{w}$ archiwum klasztornym. W swej mowie uczony miechowita dowodził, że zarówno ludzie świeccy jak i duchowieństwo sa zobowiązani do obrony kościoła katolickiego.

W dniu 19 stycznia 1562 roku uczestniczył w posiedzeniu kapituły gnieźnieńskiej, na której arcybiskupem wybrano Jakóba Uchańskiego. Występował ponadto w czasie obrad kapituły generalnej jako pełnomocnik biskupa teodozyńskiego i opata cystersów w Sulejowie, Stanisława Falęckiego przebywającego wówczas na Soborze Trydenckim. Biskup Falęcki bowiem, na prośbę prymasa Przerębskiego, uzyskał od papieża nominację na stanowisko sufragana gnieźnieńskiego. ${ }^{72}$ Pomimo oporów kapituły protestującej przeciwko mianowaniu na to stanowisko osoby spoza jej grona, w dniu 27 sierpnia 1562 roku Stanisław uzyskał ostatecznie zgodę jej członków na instalację nowego sufragana.

Stanisław z Łowicza, człowiek wykształcony, erudyta, nie mógł obejść się bez własnego, zapewne starannie gromadzonego księgozbioru. Niestety dzisiaj dysponujemy zaledwie jego szczątkami. Dotychczas odnaleziono w sumie dziewiętnaście dzieł drukowanych w dwudziestu sześciu woluminach. W tej liczbie znajdują się dwa inkunabuły. Nic natomiast nie wiadomo o kodeksach rękopiśmiennych. 
Największy zespół, liczacy 14 dzieł w 22 woluminach, przechowywany jest w Bibliotece Uniwersytetu Warszawskiego. Sa to przeważnie wydawnictwa wielotomowe, niestety $w$ większości zdekompletowane. Przeprowadzona kwerenda biblioteczna oraz poszukiwania w drukowanych katalogach poloników dostarczyły informacji o dalszych czterech pozycjach. Ponadto jeden egzemplarz odnalazłam w Bibliotece Seminarium Archidiecezji Warszawskiej.

Liczne notatki na zachowanych ksiegach pozwalaja wnioskować, że biblioteka narastała stopniowo, gromadzona prze wiele lat. Właściciel powiększał ją głównie przez stosowne zakupy. W wielu przypadkach nabywał książki wkrótce po ich wydrukowaniu. Niestety, brak jest egzemplarzy pochodzących z wcześniejszego okresu życia zakonnika. Najwcześniejsza, datowana proweniencja przypada na rok 1546 (poz. 3). Jest to zatem okres, kiedy nasz bożogrobca będąc nominalnie proboszczem we Wrocieryżu, dużo czasu spędzał w Krakowie jako kaznodzieja w kościele NMP. Większość zachowanych pozycji jednak pochodzi z ostatnich dwudziestu lat życia, z czasów prepozytury w Gnieźnie.

Obdarowywał również ksiażkami swoich współpracowników i przyjaciół. Zapisy dedykacyjne odnajdujemy trzykrotnie. Tak np. Confessio fidei Stanisława Hozjusza ofiarował w 1561 roku jakiemuś Michałowi o nieustalonym nazwisku (poz. 13). W 1567 roku podarował pisma papieża Innocentego IIl swojemu pomocnikowi i współpracownikowi Janowi Michniciusowi (Michnickiemu ?) z Włocławka (poz. 14). Był on następcą Stanisława na probostwie w kościele św. Jana. Natomiast będąc już u kresu życia, obdarował Macieja Lovitianusa (Łowickiego ?) w 1574 roku dziełem Duranda Rationale divinorum (poz. 2). ${ }^{73}$

Charakterystyka treściowa księgozbioru Stanisława nie jest łatwa, ani w pełni możliwa $z$ uwagi na szczupłość dostępnego zbioru. W zachowanych jego fragmentach najliczniej reprezentowana jest teologia, szczególnie dzieła patrystyczne. Tego typu lekturą zainteresowane były zarówno sfery akademickie, jak i zakonne. Popularne w XVI wieku były zwłaszcza wydania pism Ojców Kościoła w nowym tłumaczeniu i z komentarzami Erazma z Rotterdamu. ${ }^{74}$

W omawianym księgozbiorze spośród dzieł patrystycznych najwięcej przetrwało pism najwybitniejszego chrześcijańskiego filozofa, św. Augustyna. Zachowały się aż dwie dziesięciotomowe edycje Opera omnia tegoż świętego (poz. 3-4). Pierwsza $z$ nich, wytłoczona w latach 15281529 , pochodzi $\mathrm{z}$ bazylejskiej oficyny Johanna Frobena. Stanisław otrzymał lub kupił ją $w 1546$ roku od poprzedniego, nieznanego właści- 
ciela pieczętującego się herbem Ciołek. Dziesięć lat później nabył kolejne wydanie $z$ lat 1541-1543, pochodzące $z$ tej samej drukarni, ale prowadzonej już przez syna poprzednika, Hieronima i jego wspólnika Mikołaja Episcopiusa. Edycja ta, oparta wprawdzie na wydaniu erazmiańskim, opublikowana została $z$ poprawkami Martina Lipsiusa. Z zachowanych na ksiązkach zapisów wynika, że Stanisław kupił to dzieło w Poznaniu u księgarza Jana Patruusa 23 lutego 1556 roku za 25 florenów i dodatkowo za oprawę zapłacił jeszcze cztery floreny. Ponadto tomy te opatrzył napisem: „Pro Gloria Dei et omnium Catholicorum eruditione”.

Nasuwa się pytanie czy nasz miechowita korzystał z obydwu podobnych przecież wydań? Zapiski marginalne wskazują, że czytał uważnie, aczkolwiek być może nie w całości, oba egzemplarze. Nie można też wykluczyć, że przeprowadzając się do Gniezna, wcześniejszą edycję pozostawił w macierzystym klasztorze w Miechowie, a nastepnie dla własnego użytku, kupił kolejne nowsze wydanie. Pod koniec życia zastawił to wielotomowe dzieło u kanonika gnieźnieńskiego Jana Kąkolewskiego (Kokalewskiego) za 20 florenów. Już po śmierci Stanisława, w liście datowanym 23 kwietnia 1597 roku, kustosz miechowski zwrócił się do ówczesnego prepozyta kościoła św. Jana w Gnieźnie, Tyburcjusza Jaskłowskiego z prośbą o wykupienie tych szacownych ksiag i przesłanie do klasztoru w Miechowie jako potrzebnych dla studentów.

Stanisław, zdaje się bardzo wysoko cenił erazmiańskie edycje pisarzy patrystycznych. W jego kolekcji znajdujemy również wielotomowe wydanie pism św. Jana Chryzostoma zwanego w Polsce Złotoustym z roku 1539 (poz. 15) oraz dzieła cenionego i wpływowego teologa kościoła greckiego Orygenesa w edycji z 1557 roku (poz. 16), a także listy św. Hieronima (poz. 11). Z innych niż erazmiańskie edycji, można wymienić Opera Epifaniusza biskupa Salaminy na Cyprze i przeciwnika Orygenesa (poz. 10). Stosunkowo duża liczba wielotomowych wydań dzieł zebranych teologów wczesnochrześcijańskich pozwala przypuszczać, że także prace innych Ojców Kościoła, np. św. Grzegorza z Nazarenu, św. Bazylego czy św. Cypriana, autorów popularnych w XVI-wiecznych księgozbiorach, mogły również znajdować się w jego kolekcji.

Niezbyt licznie prezentuje się nurt dzieł egzegetycznych i dogmatycznych. $\mathrm{Z}$ tych ostatnich mamy przede wszystkim dwa wydania Confesio fidei kardynała Hozjusza, $z$ których to jedno, o czym wspomniano wyżej, podarował nieznanemu z nazwiska przyjacielowi (poz. 12-13). Ubogo przedstawia się również dział liturgii. 
Z oryginalnych dzieł XVI-wiecznych teologów mamy utwory hiszpańskiego franciszkanina Andreasa de Vegi (poz. 18-19) oraz filozofa i teologa z Rzymu Petrusa Columny Galatinusa (poz. 6).

$\mathrm{Z}$ tematyki prawniczej zachowały się jedynie zbiory ustaw soborowych i synodalnych kościoła katolickiego (poz. 1, 7).

Liczba poloników przedstawia się niezwykle ubogo. Do tej kategorii możemy zaliczyć jedynie trzy druki (poz. 8, 12-13). Wspomniany Stanislaw Hozjusz jest jedynym polskim autorem pośród wszystkich odnalezionych książek z proweniencją naszego miechowity.

Jednolicie natomiast prezentuje się omawiany księgozbiór pod względem językowym. Łacina bowiem dominuje $w$ nim zupełnie, zarówno $w$ dziełach oryginalnych, jak $\mathrm{i} w$ przekładach $\mathrm{z}$ greckiego (św. Jan Chryzostom, Orygenes), co zresztą jest, jak wiadomo, znamienne dla produkcji wydawniczej XVI wieku.

$\mathrm{Na}$ wzór innych wielkich zbieraczy renesansowych, Stanisław książki oprawiał i opatrywał znakami własnościowymi. Można wyróżnić kilka sposobów oznaczania książek. Część ksiąg ozdobiona jest superekslibrisem. Najbardziej okazały, określany przez Piekarskiego właściwym, znajduje się na oprawie dzieła Concilia omnia wydanego w Kolonii w 1538 roku (poz. 7). Miejsce herbu zajmuje godło bożogrobców, tzn. podwójnie łamany krzyż, powyżej którego rytownik umieścił główkę aniołka $\mathrm{z}$ rozpostartymi skrzydłami. W otoku umieszczono dewizę, która stanowi wers siódmy czwartego psalmu: ,signatum est svper nos lvmem vvultus tui domine". Wokół rozmieszczono litery: M/agister] S/lanislaus/ A L/owicz/. ${ }^{76}$

Drugi sposób, dość zagadkowego znakowania, znajdujemy na kilku innych oprawach. Stanowi go rodzaj superekslibrisu introligatorskiego, dodatkowo uzupełniany tłoczeniem literowym. W owych oprawach introligator posłużył się herbem Pilawa, którym pieczętowała się matka Stanisława. Taki superekslibris znajdujemy na oprawach kolejnych tomów Opera omnia św. Augustyna z 1541 r. (poz. 4). Okładzina górna (T. 2-3) jest znakowana herbem Pilawa na tarczy, natomiast na dolnej wytłoczono napis: "Doctoris Stanislai a Lowic" (!). Pełna nazwa miasta nie zmieściła się zapewne z powodu zbyt wąskiego zwierciadła. Na pozostałych woluminach $(\mathrm{T} .1-11,4,5,10)$ napis zmieniono i brzmi on: "Doctoris Stanislai lowic:".

Nieco inaczej wygląda oznaczenie oprawy dzieła Epifaniusza Contra octoaginta haereses opus Panarium... drukowanego w Bazylei w 1545 roku (poz. 10). Na okładzinie gómej mamy znów herb Pilawa 
na tarczy, powyżej którego w jednym rzędzie wytłoczono litery: S/tanislaus/D/octor/A L/owicz/, a poniżej datę 155 .

Innym świadectwem przynależności książek do zbioru Stanisława z Łowicza są zapiski rękopiśmienne. Zamieszczał je na karcie tytułowej, w ściśle określony sposób. Zwykle podpisywał się w miejscu centralnym, pośrodku karty, poniżej tytułu a przed sygnetem drukarskim. Rzadziej zapisy umieszczał pomiędzy sygnetem i adresem wydawniczym. Jedynie na egzemplarzu, uprzednio należącym do sufragana gnieźnieńskiego Sebastiana Żydowskiego, podpisał się na okładce górnej verso, pod dwoma innymi zapisami (poz. 9).

Można wyróżnić następujące, najczęściej powtarzające się formuły: "Magister Stanislaus Lowijc coenobita Miechoviensis Sacrae Theologiae professor me usu tenet" i „Sum Doctoris Stanislai Lowycz" lub podobne. Zapisy proweniencyjne informują nas nie tylko kto jest właścicielem danej książki, ale także w jakim mieście, u którego księgarza i za jaką cenę została ona zakupiona. Podawane są również okoliczności nabycia danego druku. Znajdujemy ponadto informacje o cenie oprawy, kreślone ręką posesora bądź introligatora. Daje się zauważyć, że część zapisów uzupełniono nowymi informacjami. Atramenty używane w tych zapiskach różnią się bowiem i można uznać, że po pewnym czasie pierwotną notatkę, która np. nie zawierała godności piastowanych przez właściciela, po kilku czy może nawet kilkunastu latach dopełniono. Wszystko to powoduje dodatkowe trudności przy prawidłowym ustaleniu daty zakupu danej pozycji.

Pismo Stanisława $z$ Łowicza charakteryzuje się równym, wyrobionym duktem, o stosunkowo niewielkich literach. Najczęściej używał on atramentu czarnego, a do zapisek marginalnych i podkreśleń w tekście także w kolorze czerwonym.

W książkach znajduje się wiele notatek wykonanych jego ręką. Można wyróżnić kilka ich rodzajów. Są to zapisy marginalne typu pamięciowego, poprawki korektorskie, łacińskie tłumaczenia greckich wyrazów, itd. Znajdujemy także liczne glosy odnoszące się do treści dzieła i jego wartości poznawczej, a także noty bibliograficzne. Często również Stanisław podkreślał lub zakreślał na marginesach interesujące go fragmenty tekstu. Nieraz znajdujemy na marginesie rysunek wskazującego palca znaczącego „zobacz”.

Po ilości marginaliów i podkreśleń, wnioskować można, że książki były uważnie czytane. Ślady czytelnictwa nie są jednak rozłożone równomiernie $w$ calym dziele. W wielu wypadkach znajdują się na pierw- 
szych kilkudziesięciu stronach lub innych istotnych dla właściciela fragmentach druku. Wielokrotnie licznymi komentarzami i innymi śladami lektury opatrywał wstępy i listy dedykacyjne zawierające życiorys autora druku, zwłaszcza gdy wydawca dzieła był Erazm z Rotterdamu. Tak jest w przypadku pism św. Augustyna, Orygenesa i św. Hieronima. Szczególnie gęsto opatrzony uwagami, podkreśleniami i wykrzyknikami: "Laus Erasmi Roterodami”, „Laudes Origenes" jest życiorys Orygenesa (poz. 16). Odmienny atrament w części not dowodzi, że fragment ten był czytany co najmniej dwukrotnie.

Traktat Joanniesa Reuchlina De arte cabalistica współwydany $\mathrm{z}$ dziełem Petrusa Columny Galatinusa (opus de arcanis catholicae veritatis.. (poz. 6), opatrzył uwaga „Omnigena eruditione pleni” oraz wieloma marginaliami. Książka ta dostała się później do księgozbioru kanonika gnieźnieńskiego, łowickiego i płockiego Stanisława lłowskiego, a wraz z nim do biblioteki jezuitów w Łomży. W pierwszej połowie XVII wieku, bibliotekarz jezuicki Andrzej Obrębski określił ten traktat mianem „Heretica” i zszył grubymi, Inianymi nićmi tak, aby uniemożliwic dalsze czytanie.

Odmiennego charakteru zapiska znajduje się w dziele Andreasa de Vegi Tridentini decreti de iustificatione expositio et defensio libris XV distincta... (poz. 19). Na k. 496 Stanisław zamieścił uwagę informująca że poszczególne składki dzieła zostały przez introligatora przemieszane: "In hoc libro negligens et ignarus ligator multos quaterniones mutavit leges ergo iuxta quod notatum est circa fora variata".

Do oprawiania druków należących do Stanisława z Łowicza zastosowano deskę, obciagniętą następnie brązową cielęcą skórą. Tego rodzaju oprawa wynika zapewne z faktu, że ogromna większość ksiag to pokaźnych rozmiarów folia. W jednym tylko przypadku do wzmocnienia oprawy wykorzystano makulaturę, a inny niewielkich rozmiarów druk oprawiono w pergamin. Oprawy były dodatkowo zaopatrzone w klamry, dziś zachowane jedynie w szczątkowej postaci

Jako elementy zdobnicze okładzin szeroko wykorzystywano zarówno tłoczenie złotem, jak i ślepe. Badając zastosowane do ornamentyki radełka i tłoki, można wyróżnić co najmniej dwa ośrodki introligatorskie. Jednym z nich jest Kraków. Do tego kręgu możemy zaliczyć trzy oprawy. W najbardziej okazała oprawę wyposażono dzieło ( 'oncilia omnia, wydane pod redakcją Petrusa Crabbe w 1538 r. (poz. 7). Zwierciadło okładziny górnej wypełnia tłoczony złotem, omówiony wyżej superekslibris właściwy z godłem bożogrobcow, bordiurę natomiast stanowi radełko 
,jagiellońskie" z powtarzającymi się postaciami: SIGISMUN/dus/, BONA, SIGIS/mundus/AUG/ustus/, ISABELLA. Radełko to przy wizerunku Bony jest datowane na rok $1540 .{ }^{77}$ Natomiast zwierciadło okładziny dolnej jest w całości wypełnione radełkiem z postaciami biblijnymi, datowane również na tenże rok 1540. Do tej grupy można również zaliczyć oprawę dzieł św. Jana Chryzostoma (poz. 15), z których do dziś przetrwały jedynie dwa woluminy zawierające tomy $1-2$ i 5 . Otrzymały one zabezpieczenie skórzane ozdobione niejednolicie. Tom 5 ma na okładzinie górnej wytłoczony na zbyt małym zwierciadle superekslibris $\mathrm{z}$ herbem bożogrobców ale już bez inicjałów. Bordiurę natomiast wypełnia radełko z postaciami Apostołów: MARCUS, LUCAS, IOANNES, MATHEUS, datowane przy figurze św. Marka „1540”. W wolnej przestrzeni pomiędzy radełkami, oryginalnym pojedynczym tłokiem odbito wizerunek siedzącej na gałęzi sowy, symbolu mądrości. Natomiast w tomie 1-2 zwierciadło okładziny górnej jest sporo większe i superekslibris, mieści się swobodnie, radełko jest takie samo, zaś tłoki przedstawiaja główki uskrzydlonych aniołków. Oprawę krakowską mają także dzieła wszystkie św. Augustyna w wydaniu z lat 1528-1529 (poz. 3). W zwierciadle okładki gómej wytłoczony jest herb Ciołek na tarczy, a bordiure wypełnia radełko z postaciami podpisanymi $S A L V A T O R$, PETR/us/, PAULUS, datowane „I540", znane także z opraw króla Zygmunta Augusta. ${ }^{78}$

Drugi charakterystyczny typ opraw mają książki, zakupione u Jana Patruusa w Poznaniu lub Gnieźnie i oprawiane przez działającego w Poznaniu introligatora o inicjałach ,MC"'. 79 Takie, prawie identyczne oprawy, otrzymały pisma Orygenesa w wydaniu bazylejskim Frobena i Episcopiusa (poz. 16) oraz komentarze do Starego i Nowego Testamentu św. Augustyna, również drukowane w Bazylei (poz. 5). Przy obu oprawach wykorzystano m.in. dwa radełka ze scenami figuralnymi: $S A$ LVATOR, EGO SUM PAS/tor Bonus/, CAP/e/ CRIJlcem/S/uam/, SUR/ge/ ET VADE, z inicjałami ,MC" przy postaci Chrystusa Dobrego Pasterza oraz drugie oznaczone LU(IRE(IA, PRIII)EN/Cial, IUSTICIA i postać bez podpisu z data , $15+3$ ". Inicjały , $M C^{n}$ " wplecione sa w ornamentykę postaci Lukrecja. Do zasobu tego introligatora należało także radełko oznaczone SALVATOR, MATELS, MARCUS, LUCAS, IOHANNLS z wplecionymi w ornament powyżej postaci św. Marka inicjałami „MC", wytłoczone jedynie na oprawie dzieła św. Augustyna (poz. 5). Mimo tego, że radełka z inicjałami , $M("$ "znane są również z opraw Krakowa, Wrocławia i Chelmna, $z$ dużym prawdopodobienstwem można 
uznać, że te właśnie książki były oprawiane w Poznaniu. O innej poznańskiej okładzinie, ozdobionej radełkami z inicjałami , $M C$ " pisała Maria Krynicka. ${ }^{80} \mathrm{Na}$ oprawie dzieła św. Augustyna (poz. 5) znajdujemy ponadto radełko $\mathrm{z}$ postaciami alegorycznymi podpisane PRUIDENCI/a], IUDIT[a], LUCRECI/a], oraz nieoznaczone [Suavitas], sygnowane "I5NP58". Jest to radełko szczególnie popularne na XVI-wiecznych, niemieckich oprawach. Jego twórca był znany jedynie pod inicjałami „NP" rytownik działający na obszarze dolnego Renu. ${ }^{81}$ Warto zauważć, że w oprawach poznańskich Stanisław nie używał już superekslibrisu z podwójnym krzyżem bożogrobców. Został on zastapiony herbem Pilawa na okładzinie górnej i tłoczeniami literowymi na okładzinie dolnej (poz. 4, 10).

Omawiany księgozbiór po śmierci właściciela włączono do książnicy siedziby generalnej bożogrobców w Miechowie. Świadczą o tym sygnatury, zwykle umieszczane na wyklejce górnej verso. Innym charakterystycznym dla biblioteki miechowskiej znakiem są litery C/onvenut] M[iechoviensis/ oraz znajdujacy się pomiędzy nimi podwójny krzyż bożogrobców, rysowane najczęściej na obcięciu górnym lub rzadziej na obcięciu dolnym. ${ }^{82}$

Do naszych czasów zachował się, jak już wspomniano, niestety jedynie niewielki fragment zbioru Stanisława $z$ Łowicza. Kolekcja nie przetrwała konfrontacji $\mathrm{z}$ wielokrotnymi pożarami, sekularyzacja zakonu bożogrobców i dalszymi burzliwymi losami bęącymi udziałem wszystkich bibliotek w Polsce. Niezwykle trudno jest zatem choćby szacunkowo obliczyć jej wielkość. Trudno także przeprowadzić stosowne studia porównawcze, bowiem niewiele jest w naszej literaturze opracowań lub prób rekonstrukcji księgozbiorów należących do zakonników, zwłaszcza XVI-wiecznych. Jako przykład do porównania może posłużyć księgozbiór starszego nieco od Stanisława z Łowicza dominikanina Feliksa z Sieradza (1537-1602) herbu Gozdawa, doktora teologii i kaznodziei Kościoła Mariackiego w Krakowie. Swoją liczną bibliotekę podarował on konwentowi w Sieradzu. Biblioteka Seminarium Duchownego we Włocławku przechowuje jego księgozbiór liczący obecnie 52 woluminy dzieł o treści religijnej. ${ }^{83}$ Żyjący współcześnie z Feliksem z Sieradza Maciej Bech (zm. 1607), herbu Rogala, prepozyt sandomierski i kazimierski miał także spory zbiór ksiag, które oznaczał 6 odmianami superekslibrisu ze znakiem swojego rodu. Mamy wiadomość o 57 egzemplarzach z tej kolekcji. ${ }^{84}$ 
Podobnej wielkości był zapewne zbiór naszego miechowity. Wydaje się, że nie był on człowiekiem zbytnio zamożnym, co przy wysokich cenach książek w XVI stuleciu utrudniało zgromadzenie bardzo licznej kolekcji ksiażzowej. Biorąc jednak pod uwagę obecność monumentalnych, wielotomowych edycji dzieł zebranych pisarzy patrystycznych, można z dużą dozą ostrożności uznać, że zbiór pierwotnie mógł przekroczyć liczbę 100 pozycji. Posiadanie supereklibrisu właściwego sugeruje również zwykle istnienie większego zespołu.

Zachowany fragment pozwala jednak w dużym przybliżeniu określić charakter tej biblioteki. Był to księgozbiór o wyraźnie zaznaczonym charakterze użytkowym, inspirujacy w codziennej pracy duszpasterskiej i kaznodziejskiej oraz potrzebny do wypełniania innych publicznych obowiązków w obrębie struktur kościelnych. Był on zapewne niezbędny również w pracy naukowej uprawianej przez uczonego teologa, apologety chrześcijaństwa i przeciwnika reformacji. Nasz bożogrobca był bowiem gorącym zwolennikiem reformy kościoła katolickiego w duchu erazmiańskim oraz postanowień Soboru Trydenckiego. Gromadził i czytał dzieła Ojców Kościoła w nowatorskim wydaniu Erazma z Rotterdamu, a także studiował prace zawierające dekrety Soboru Trydenckiego. Nie unikał jednak nowinek reformacyjnych, o czym świadczy obecność w jego zbiorze dzieła znanego wolnomyśliciela i krzewiciela reformacji, Joannesa Reuchlina De arte cabalistica.

Jakkolwiek kolekcję Stanisława z Łowicza trudno określić jako bibliofilska, jej właściciel nie pozostal obojętny na wpływy i mody estetyczne epoki. Świadczy o tym dbałość o szatę zewnętrzną swoich ksiag, a także opatrywanie ich charakterystycznymi dla tego wieku odręcznymi zapiskami wyrażającymi uczuciowy stosunek do książki. Właściwa dla epoki jest również obfitość w zbiorze dzieł teologicznych. Nie bez wpływu zapewne na takie, a nie inne ukształtowanie kolekcji był fakt, że jako członek zakonu posługującego się regułą św. Augustyna, której jedną $\mathrm{z}$ zasad jest ubóstwo, nie mógł mieć w posiadaniu książek o innym charakterze, niż użytkowy.

Prezentowany księgozbiór pozwolił wydobyć z zapomnienia postać wykształconego, szesnastowiecznego zakonnika będącego członkiem wspólnoty bożogrobców. Ukazuje on swojego właściciela jako człowieka już w pełni ukształtowanego przez Renesans, światłego zakonnika, zainteresowanego nowymi prądami w kościele katolickim. Jego biblioteka jeszcze przez wiele lat dobrze służyła w Miechowie następnym pokoleniom braci zakonnej. 
Spis ksiażek z księgozbioru Stanisława z Łowicza

Opisy pozycji $\mathrm{nr} 1,2,8,13$ przejęto $\mathrm{z}$ katalogów drukowanych, a opisy pozostałych pozycji sporządzono $\mathrm{z}$ autopsji. W cytacie bibliograficznej uwzględniono jedynie podstawowe pozycje $\mathrm{z}$ literatury polskiej $\mathrm{i}$ obcej.

\section{Wykaz skrótów cytowanej literatury}

Adams - H.M.Adams: Catalogue of books printed on the continent of Europe 1501-1600 in Cambridge Libraries. Vol. 1-2 Cambridge 1967

BLC - The British Library general cataloque of printed books to 1975. Vol. 1-320. London 1980-1985

BUW - Katalog druków XV i XVI wieku w zbiorach Biblioteki Uniwersyteckiej w Warszawie. T. 1. Oprac. T.Komenderowa. Warszawa 1994

CBN - Catalogue général de livres imprimés de la Bibliothèque Nationale. Auteurs. T. 1-231. Paris 1924-1981

Cat.Esp. - Catalogo colectivo de obras impresas en los siglos XVI al $X V I I I$ existentes en las bibliotecas españolas. Seccion 1. Siglio XVI. T. 1-8 (A-L) Madrid 1972-1976

E - K.Estreicher: Bibliografia polska. T. 12-34, wiek XVXVIII. Kraków 1882-1951

IA - Index Aureliensis. C'atalogus librorum sedecimo saeculo impressorum. T. 1-9. Baden Baden 1965-1991

IBP - Incunabula quae in bibliothecis Poloniae asservantur. Composuerunt M.Bohonos, E.Szandorowska. T. 1-2. Wratislaviae 1970

Jędrzejowska, Pelczarowa - Katalog inkunabulów Biblioteki Miejskiej w Gdańsku. Oprac. M.Jędrzejowska i M.Pelczarowa. Gdańsk 1954

Ossol - Katalog starych druków Biblioteki Zakladu Narodowego im. Ossolinskich. Polonica wieku XVI. Oprac. M.Bohonos. Wroclaw 1965 
Ossol.Gryczowa - Katalog inkunabulów Biblioteki Zakladu im.

Ossolińskich. Oprac A.Kawecka-Gryczowa. Wrocław 1956

VD - Verzeichnis der deutschen Sprachbereich erschienenen Drucke des 16. Jahrhunderts. Hrsg. von der Bayerischen Sta atsbibliothek in München in Verbindung mit der Herzog August Bibliothek in Wolfenbüttel. Red. I.Bezzel. Bd. 1-18. Sttutgart 1983-1990

W - T.Wierzbowski: Bibliographia polonica XV ac XVI ss. T. 1-3. Varsoviae 1888-1894

\section{XV wiek}

1. CONCILIUM Constantiense: Acta et decreta. Ed. iussu Iacobi Locheri et Conradi Summenhart. Hagenau: Henr. Gran pro Io . Rynman, 11 IV $1500.4^{0}$

IBP 1671. Ossol.Gryczowa 92

Prow.: 1) Sum doctoris Stanislai theologi praepositi Ecclesiae S[an]cti Ioannis ante Gnezam 1557.

2) Iste libellus d. Stanislai Mtodzieiowsky rc. datus Dobie slao Strzeżowski Notario sanctae Mariae, [zamazane] XVI w.

3) Ioannis Zdrowski Bacc/alaurei] - XVI/XVII w.

4) Biblioteka Brodzkich - piecz. - XIX w.

Opr:: deska, skóra brun., tłocz. ślepe - XVI w.

2. DURANDI Guilielmus: Rationale divinorum officiorum. Strassburg [Typ. Iordani $=$ Ge.Husner, non post 6 X 1484]. $2^{0}$

IBP 2023 Jędrzejowska, Pelczarowa 230

Prow.: 1) Sum Doctor[is] Stanislai Lowycz p[rae]p[osi]ti

S.Joannis ante (ineznam fida suppellex. Empt/us] $24 \mathrm{gr}$.

- XVIw. 
2) Me possidet Mathias Louitaian[us/ a D/omi]no Sta/nisla /o Doctore beda donatus. An/n]o Ch/ist/i 1574

3) Boleslaus Strzezowski Rosanus [powyżej herb Poraj rys. atr.] - XVI w.

4) Matthaei Rautenberg Arch/i]d[iaconi] et Off[iciallis] Cam[er]e no[mi]n/e] p[ro]p[rio] - XVII w.

5) Inscriptus Catalogo Fr[atru]m de Oliuia - XVII w. Mon[aste]rji Oliven[sis] Ord[ini]s Cist[erciensium] in Prussia - XVIII w.

6) B[iblioteka] M[iejska w] Gd[ańsku] XX.B.63

Opr.: po 1945; dawniejsza oprawa XVI-wieczna z herbem Poraj zachowana.

Gdańsk PAN XV.454

\section{XVI wiek}

3. AUGUSTINUS Aurelius s.: Omnium operum primus [-decimus] tomus, summa vigilantia repurgatorum a mendis innumeris per Des[iderium] Erasmum Roterodamum... Basileae: in. off. Io. Frobenii, 1528-1529 [rz.]. $2^{0}$ T.:7, 9, 10, 11

\section{IA 110.175. Adams A-2157 VD-A 4148 BUW A-573}

Prow.: 1) herb Ciołek, 1541 - superekslibris,

2) Magister Stanislaus Lowijcz coenobita Miechovien[sis] Sacrae Theologiae professor me usu tenet.

W t. 9 ten sam zapis zaczynający się Anno Domi[ni] 1546... W t. 11: M[a]g[iste]r Stanislaus Lowijcz coenobita Miechoviensis Sacrae Theologiae professor me usu tenet cum Decem Divi AurelijAugustini tomis; sentencja łac. tą samą ręka.

3) Clonventus] $\ddagger$ M/iechoviensis] oraz sygnatury bibl. miechowskiej i nalepka rps - XVII w.

Marginalia Stanisława z Łowicza i inną ręką XVI w.

Opr.: deska (T. 11 makulatura, tekst hebr.), skóra brun., tłocz. złoc. i ślepe, radełko, tłoki, resztki klamer - XVI w. 
4. - -: Omnium operum... primus [-decimus] tomus ad fidem vetustorum exemplarium... summa viligantia repurgatorum a mendis innumeris... [Ed. Erasmus Desiderius Roterodamus et corr. Martinus Lipsius]. Basileae: per Hier. Frobenium et Nic. Episcopium, 1541-1543 [rz.]. $2^{0}$. T: $1-3,6-7,11$

\section{IA 110.256. Adams A-2162. BLC 13,498. VD-A 4149. BUW A-574}

Prow.: 1) Doctoris Stanislai Lowicz - tłocz. na okł. d. oraz herb Pilawa, 1556 - superekslibris Anno Domini 1556 Die 23 [rz.] Februarij Posnaniae M[a]g[iste]r Sta[nislaus] a Lowijcz, Sacrae Theologiae Professor, Eccllesi Jae S. Joannis ante Gneznam praepositus, Ordinis Militiae S. Sepulchri Domini Hierosolymitani, omnes tomos Operum Divi Augustini apud Ioannem Patruum, civem bibliopolam Posnanien/sem] florenis viginti quinque emit. [dopisane inną ręka] atque ligatura flor/enis/ 4. [in. atr.] pro gloria Dei et omnium catholicarum eruditione

W T. 8 i 10: Sum Doctoris Theologii Stanislai a Lowijcz fida suppellex

W T. 9: Doctoris Stanislai Theologii a Lowijcz praepositi S.Ioan[nis/ an[te] Gneznam pro festi Miechov[iensis] sum fida suppellex.

2) Omnia opera Sancti Augustini apignorata erant per R[evere]ndum Stanislaum a Lowicz apud dominum Ioannem Kakaliewski, (anonicum Gnesnen/sem/ in viginti florenis; repignorata sunt per me Tiburcium Jasklowskj, praepositum S.Ioannis (Inesnen[sis] et pro fratribus Conventus Miechovien/sis/donata.

$\mathrm{Na}$ ost. k. T. 1 list kustosza miechowskiego z 23 IV $1597 \mathrm{r}$. do T. Jaskłowskiego z prośbą o wykupienie zastawionych przez zmarłego Stanisława $z$ Łowicza dzieł św. Augustyna i przesłanie ich jako bardzo potrzebnych klasztorowi. Na tejże k. verso odpowiedź T. Jaskłowskiego: Decem volumina Divi Augustini a R/evere/ndo I/omi/no Ioanne Kakalewskj in 20 fl/orenis / opignorata, Fratribus meis et Conventui Miechoviensi, et summam pecuniaram et volumina Divi Augustini, pro uno l'ater noster et Ave Maria dono do et summam 
dimitto per meum vectorem. Frater Tiburicius Jasklowskj praep[osi]tus S.Ioannis extra Gnesnam, professus Miechovien[sis].

3) C[onventus] $\ddagger$ M[iechoviensis] oraz sygnatury bibl. miechowskiej.

Marginalia Stanisława z Lowicza i inną ręką XVI w.

W T. 1 na marginesach figury geometryczne.

Opr.: deska, skóra brun., tłocz. ślepe i złoc., radełko, tłoki, resztki klamer - XVI w.

BUW Sd.602.267

5. - -: Tam in Vetus quam in Novum Testamentum commentarii ...iam primum per loannem Gastium... in lucem editi... [T. 1-2]. Basileae: per Io. Hervagium, [po 4 IV] 1542 [rz.]. $2^{0}$. T. 1

IA 110.264. Adams A-2186. BLC 14,8. CBN 5,388-9.

VD-A 4159. BUW A-585

Prow.: 1) wycięta,

2) Sum Doctoris Stanislai Lowijcz (Posnaniae in foro scrutario uno floreno) praepositi S.Joannis Gnesnen[sis].

3) [Bożogrobcy-Miechów] - sygnatury

Marginalia Stanisława z Łowicza i inną ręka XVI w.

Opr.: deska, skóra brun., tłocz. ślepe i złoc., radełko, tłoki, resztki klamer - XVI w.

BUW Sd.602.224

6. COLUMNA Petrus Galatinus: Opus de arcanis catholicae veritatis hoc est in omnia difficilia loca Veteris Testamenti, ex Talmud, alijsque Hebraicis libris contra obstinatum Iudaeorum perfidiam... commentarius. Ad haec Ioannis Reuchlini... De arte cabalistica libri tres... Basileae: exc. Io. Hervagius, 1550 [rz.]. $2^{0}$

Adams C-2419. BLC 67,15. VD-C 4615 
Prow.: 1) [Stanisław z Lowicza/Anno Do/mini/ 1556 pro ferijs divi Adalberti Gneznae 2 Talaris

2) [Stanisław Iłowski] - XVI w.

3) d[ono] d[atus] a DD[ominis] Ilovijs An[no] 1613 - ręką A.Obrębskiego

4) Inscriptus (atalogo Libroru[m] Soc/ietatis] Jesu Collegij Lomzen[sis] - XVII w.

5) Stefan Bartek - XVIII w., - czy prow.?

Marginalia Stanisława z Łowicza i Stanisława Iłowskiego.

Dzieło I.Reuchlina De arte cabalistica libri tres zaszyte przez bibliotekarza jezuickiego A.Obrębskiego.

Opr.: deska, sk. brąz., tłocz. ślepe, śl. klamer - XVI w.

BUW Sd.602.1340

7. CONCILIA: Concilia omnia, tam generalia quam particularia, ab apostolorum temporibus in hunc usque diem a sanctissimis patribus celebrata... his duobus tomis continentur... [Ed. Petrus Crabbe]. Coloniae: Petr. Quentel exc., IX 1538 [rz.]. $2^{0}$ T. 1

Adams C-2769. BLC 71.110. VD-C 5643

Prow.: 1) M[agister] S[tanislaus] A L[owicz] - tłocz., oraz krzyż bożogrobców, w otoku napis: Signatum est super nos lumen vultus tui Domine (Ps. 4, 7), 1547 - superekslibris (Sipayłło tabl. 11) 2 tomi Conciloorum florenis quinque sine $6 \mathrm{~g} /$ rossis/ M/agister/S/tanislaus] L/ovicensis/ 1547 mense Martio.

M/agister/Sta/nisla/us Coenobita Miechov/iensis/S.

T'heologiae / P/rofessor] me usu tenet.

2) C/onventus / $\neq \mathrm{M} /$ iechoviensis/ oraz sygnatury biblioteki miechowskiej.

$\mathrm{Na}$ okładce d. verso cytat z psalmu.

Nieliczne marginalia Stanisława z Łowicza.

Opr. : deska, sk. brąz., tłocz. złoc., radełko, tłoki, resztki klamer XVIw. 
8. DIURNALE: Diurnale secundum usum ecclesiae Cracoviensis... Cracoviae arte et impens. Joh. Haller, $1514.8^{0}$

E 25, $241 \quad$ Ossol. 624

Prow:: 1) Ex libris fratris Stanislai a Łowicz - XVI w.,

2) No 19 consig.

3) Biblioteka Poturzycka J.W.D[ieduszyckich] 60 - piecz.

Marginalia XVI w.

Opr.: deska, sk. braz., tłoki, radełko, plakietka, resztki klamer XVI w.

Ossol. VI.0. 134

9. ENARRATIONES: Enarrationes vetustissimorum theologorum in Acta Apostolorum et in omnes ...Pauli ac catholicas epistolas ab Oecumenio, in Apocalypsim vero ab Aretha... collectae Ioanne Hentenio interprete... Praetera Remigii Altissiodorensis... in undecim posteriores Prophetas enarratio. Antverpiae: in aed. Io. Steelsi, V 1545 [rz.]. $2^{0}$

Adams O-112. BLC 30, 286

Prow.: 1) Sebastianus Żydowski Episcopus Naturiensis, herb Doliwa, 1549 - superekslibris Jego ręką: Reverendissi]mus D. Naturien[sis] E[pisco]pus emit grossis quinquaginta 1549.

2) Emptus iste liber flo/reno] 1 et $18 \mathrm{~g}$ [rossis] apud d[omi]num Zidowskij 1574 per Stanislaum Venatorium doctorem Theologum praep/osi/tum S. Joannis ante Gneznam.

3) C[onventus] $\ddagger M$ [iechoviensis/ oraz sygnatury biblioteki miechowskiej i nalepka rps - XVII w.

Opr.: deska, sk. braz., tłocz. złoc., radełko, resztki klamer - XVI w. 
10. EPIPHANIUS ep. Constantiae in Cypro: Contra octoaginta haereses opus Panarium sive Arcula aut Capsula Medica appellatum, continens libros tres, et tomos sive sectiones ex toto septem, Iano Cornario... interprete... Basilieae: per Rob. Winterum, IX 1545 [rz.]. $2^{0}$

Adams E-253. BLC 101,479. VD-E 1645

Prow.: 1) S[tanislaus] D[octor] A L[owycz] - tłocz. oraz herb Pilawa, 1557 - superekslibris,

Sum doctoris Stanislai theologi p[rae]p[ositi] S. Loannis

Gnesnen/sis/ 2 Martii Posnaniae 1557

2) [Bożogrobcy - Miechów] - sygnatury,

Marginalia Stanisława z Łowicza i inną ręka - XVII w.

Opr.: deska, sk. brąz., tłocz. ślepe i złoc., radełko, tłoki, resztki klamer - XVI w.

BUW Sd.602.1385

11. HIERONYMUS s.: Epistolarum opus... in tres tomos distinctum una cum scholiis Des/iderii] Erasmi Roterodami postremum per eundem... recognitum, correctum ac locupletatum. Basileae: ex off. Frobeniana, per Hier. Frobenium et Nic. Episcopium, 1543 [rz.]. $2^{0}$.

Cat. Esp. J-229

Prow.: 1) Anno Do[min] 1552 Mense Martio florenis tribus Piotrcoviae [innym atr.] Stanislaus Lovicen/sis/ artium et theologiae professor praepositus Eccl [esi]ae S. Ioannis ante Gneznam, militis sancti sepulchri Domi/ni] Hierosolijmitani me usu tenet.

2) Clonventus $\neq M$ /iechoviensis] oraz sygnatury biblioteki miechowskiej i nalepka rps - XVII w.

Marginalia Stanisława $z$ Łowicza.

Opr.: deska, sk. brun., tłocz. ślepe, radełko, tłoki, resztki klamer XVI w. (grzb. po konserwacji) 
12. HOSIUS Stanislaus: Confessio fidei catholicae christianae... Pars prima. Cracoviae: in off. haer. Mar. Scharffenberger, 1553. $8^{0}$

E $18,278 \quad$ W139

Prow.: 1) Sum M[a]g[ist]ri Stanislai Lovicen/sis] Sacrae Theologiae p[rolfessoris 155325 Martii gr[ossis] 22.

2) V[e]n[era]b/i]li P[at]ri F[rat]ri Philiberto Przysiecki donavit F[rater] Josephus m[anu] p[ropria] - XVII w.

Liczne marginalia Stanisława z Łowicza

Opr.: deska, skóra brun., tłocz. ślepe i złoc., plakietka z wyobrażeniem Chrztu św., strychulec, tłoki, resztki klamer - XVI w.

BUW 28.1.17.37

13. - -: Confessio catholicae fidei christiana... Pars prima. Viennae: in off. Mich. Zymmermannii, 1560 [rz.]. $2^{\circ}$. Wyd. B

E 18.279. W 2357. VD-H 5141

Prow.: 1) Stanislaus a Łowicz [?] Michaeli Rad... ergo amoris dedit 1561

2) Joannis Żardecki Decani Chelmen[ensis] - XVI w.

3) Conventus Cracovien[sis] SS. Trinit/atis] post mortem P[atri] Adami m[a]g[ist]ri - XVI w.

4) [J. M. Ossoliński] 9457.

Marginalia - XVI w.

Opr.: perg., resztki wiązań - XVII w.

Ossol. XVI.F.4078

14. INNOCENTIUS III, papa: Opera... quae quidem hactenus obtineri poturerunt omnia... et partim iam primum in lucem edita... Coloniae: exc. Io. Novesianus, $1552[\mathrm{rz}.] 2^{0}$

Adams I-121. BLC 159,13. VD-I 221

Prow.: 1) Grossis 54 Piotrkoviae sub Sijnodo anno D/omi]ni $155+$ me redemil Doctor Stanislaus Lowicz mense Octobri. 
2) Et Joanni Mich[nicii] Vlad[islavi]en[si] S. Theo[logiae] Bacc/alaure lo Anno Salutiferi partus 1567 die 21 mensis Augusti is idem dedit, ut suo coadiutori.

3) Post obitum A[dmodum] R[everendi] Do[mini] Sisinij Canonici Vladislau[iensis] Conventui Petr[icoviensis] Ord[inis] Praed[icatorum] applicatur.

Marginalia Stanisława z Łowicza i inną ręką - XVI i XVII w.

Opr.: deska, sk. braz., tłocz. ślepe, radełko, tłoki, resztki klamer XVI w.

15. IOANNES Chrysostomus s.: Opera... quotquot per Graecorum exemlarium facultatem in Latinam linguam hactenus traduci potuerunt... [T. 1-5] Basileae: ex off. Hervagiana, 1539 [rz.] $2^{0}$ T. 1-2, 3

Adams C-1516. VD-J 400

Prow.: 1) [Stanisław z Łowicza] krzyż bożogrobców, 1546 - superekslibris,

Opera divi Chrysostomi Anno Domini MDXLVI empta mense Augusto florenis XI cum X g[rossis] M/a]g[iste/r Sta[nisla] us Lovicen[sis] Miechowien[sis] Coenobita emit. Impensis sectabilis viri Domi/ni/ Georgij Egiel, Dominorum Fucarorum notarij, Eo tempore cum Concionaretur Crac[ovi]ae apud S. Stephanum [dalej innym atr.] M[a]g/iste]r Stanislaus Lowijcz coenobita Miechovien[sis] Sacrae Theologiae professor me usu tenet cum ceteris to mis eadem ligatura et Xaractere obsignatos. 2) C[onventus] $\ddagger$ M[iechoviensis] oraz sygnatury biblioteki miechowskiej i nalepka rps - XVII w.

Nieliczne marginalia Stanisława z Łowicza

Opr.: deska, sk. brąz., tłocz. ślepe i złoc., radełko, tłoki, resztki klamer - XVI w.

BUW Sd. 602.1230 
16. ORIGENES: Opera quae quidem extant omnia per Des[iderium] Erasumum Roterodamum partim versa et viliganter recognita, partim ab aliis... translata... P. 1-2. Basileae: per Hier. Forbenium et Nic. Episcopium, VIII $1557[\mathrm{rz}.] 2^{0}$

Adams O-284. VD-O 910

Prow.: 1) Doctor Stanislaus Lowijcz redemit flor/enis] sex thomi[!] duo 1558 apud Joannem Patruum bibliopolam Posnanien[sem].

W T. 2: Sum Doctoris Stanislai a Lowycz prae[posi]ti Ecc[lesi]ae S. Joan/nis/ an[te] Gneznem.

2) C[onventus] $\neq M$ /iechoviensis].

Marginalia Stanisława z Łowicza

Opr.: deska, skóra brąz., tłocz. ślepe i złoc., radełko, tłoki, resztki klamer - XVI w.

BUW 7.12.1.10

17. POLUS Reginaldus: Libri duo... Primus liber de Concilio...alter de reformatione Angliae... Interseritut... disputatio de baptismo Constantini Magni imperatoris... Dilingae: exc. Seb Mayer, 1562 [rz.]. $8^{0}$

BLC 261,468. VD-P 3923

Prow:: 1) D[octor] S/tanislaus] Lovijcz p/rae]p[osi]tus S. Joannis (ineznen/sis], [skreślone],

2) Sum fida suppellex Stanislai Bobrowskij Eccl[esi]ae

S.Sepulchri Jero/so/li/mi/tani militis Anno Do/min] 1561

[! - książka wyd. w1562] Emptus 24 g[rossis],

3) C[onventus] $\neq$ M/iechoviensis/ oraz sygnatury biblioteki miechowskiej.

Marginalia Stanisława z Łowicza i iną ręką - XVI w.

Opr.: deska, skóra brąz., tłocz. ślepe, radełko, resztki klamer - XVI w. 
18. VEGA Andreas: De iustificatione doctrina universa libri $X V \ldots$ Coloniae: apud Gerv. Calenium et haer. Quentelios, 1572 [rz.] $2^{0}$

Adams V-321. BLC 337,428. CBN 204,705

Prow.: 1) Anno Domini 1573 Gnezne apud patruum Bibliopolam posnanien[sem] pro florenis 4 emit D/octor] Stanisla/us] Lowicz.

2) C[onventus] $\$$ M[iechoviensis] oraz sygnatury biblioteki miechowskiej.

Opr.: deska, skóra braz., tłocz. ślepe i złoc., radełko, plakietka z głową Chrystusa - XVI w.

BUW 7.36.1.7

19. - -: Tridentini decreti de iustificatione expositio et defensio libris $X V$ distincta... Venetiis:ad signum Spei, $15484^{0}$

CBN 204, 705

Prow.: 1) Anno domini 1552 piotrkoviae sub Comitijs Mense Martio Quaterniones una Sexagena Ligatura grosisi septem [innym atr.] Magistri Stanislai SacraeTheologiae Sancti Joannis apud Gneznam praepositi sum fida suppllex.

2) Inscriptus Catalogo librorum Collegij Calissiensis Societatis Iesu - XVII w.: Na grzbiecie ślady czerwonej farby [=Jezuici-Kalisz],

3) Seminarii Generalis Varsaviensis - XIX w.

Marginalia Stanisława $\mathrm{z}$ Łowicza

Opr.: papier, perg., wiązania - XVI w.

Bibl. Sem. Warsz. F. 44. 2

Praypisy:

S.Nakielski: Miechovia sive promptuarium antiquitatum Monasterii Miechoviensis... Cracoviae, in off. Fr. Caesarii, $16342^{0}$

${ }^{2}$ M.Tobiasz: Bozogrohcy u' Micchowie. w: Nassa Praeszlosic Krakow T. 17: 1963 S. $5-60$ 
${ }^{3}$ Z.Pęckowski: Miechow. Studia z dziejów miasta i ziemi miechowskiej do roku 1914. Kraków 1967

4 Pełne zestawienie literatury zob. hasło "Bosogrobcy" w: Fincyklopedia Katolicka. T. 2 Lublin s. 878-882. Ponadto z ostatnich lat wymienmy: H.Piwoński: Antyfonarz bożogrobców z Miechowa w: Musica medii Aevii R. 61977 s. 87-140; tenże: Liturgia wielkoc:warlkowa u bożogrobców w: Archiwum Bibliotek Muzycznych R. 351977 s. 215-230; W. Oblizajek: Najstarsze dokumenty bozogrobców miechowskich w: Studia Źródtoznawcze T. 241979 s. 97-108; E.Potkowski: Ksiązka rękopiśmienna w kulturze Polski średniowiecznej. Warszawa 1984; J.Staszel: Miechów, jego dzieje w relacji Kazimierza Girtlera w: Rocznik Biblioteki PAN w Krakowie R. 291984 s. 225-246; Zbiory rękopisów w bibliotekach i muzeach w Polsce (zbiory kościelne). Oprac. D.Kamolowa przy współprac. K.Muszyńskiej. Warszawa 1988; M.Sipayłło: Polskie superekslibrisy XVI-XVIII wieku w zbiorach BUW. Warszawa 1988

${ }^{5}$ P.Bohman, J.K.Wietz: Rys historyczny zgromadzeń zakonnych obojej ptci. T. I Zakony męskie. Warszawa 1848 s. 58-59

${ }^{6}$ G.Labuda: Jaksa z Miechowa. PSB T. 10 s.340-341; M.Tobiasz:op. cit. s. 9: Z.Pęckowski: op. cit. s. 304

${ }^{7}$ Miechów otrzymał prawa miejskie dopiero w $1290 \mathrm{r}$.

${ }^{8}$ M.Tobiasz: op cit. s. 15-18, 20-30; W.Oblizajek: op. cit. s. 103-105; Z.Pęckowski: op. cit. s. 299-305, 310

${ }^{9}$ M.Tobiasz: op. cit. s. 43

${ }^{10}$ tamże, s. 22

1 J.Gacki: Bożogrobcy w: Pamiętnik religijno-moralny R. 121853 nr 3 s. 229

${ }^{12}$ L.Hajdukiewicz: Biblioteka Macieja z Miechowa. Wrocław 1960 s. 26

${ }^{13}$ H.Barycz: Historia Uniwersytetu Jagiellonskiego w epoce humanizmu. Kraków 1935 s. 131

14 J.Gacki: op. cit. S. 231

${ }^{15}$ M. Tobiasz: op. cit.s. 23; Z.Pęckowski: op. cit.s. 362

${ }^{16}$ M.Buliński: Wiadomości historyczne o Zakonie Kanoników Regularnych, Stróżów Grobu Chrystusowego w: Pamiętnik religijno-moralny R. 11 1825 nr 5 s. 479; F.Radziszewski: Wiadomośc historyczno-statystyczna o znakomitszych bibliotekach $i$ archiwach publicznych i prywatnych. Kraków 1875 s. 48

17 W liście do Stanisława Kostki Potockiego z dn. 8VIII 1819 r. Linde pisze „Biblioteka Miechowska, chociaż przez hubowników, wędrowników i okolicznosici czasowe dosyć byta nadwyrę̇̇ona, jest atoli tak licznq, żem po trzech dniach dopiero ukonczyt jej przejrzenie. Co do ważności nie wiem, czy ustępuje Sw. Krzyskiej [Benedyktyni, przyp. aut.]. Zebrałem sztuk 4644.... Inkwnabutów moze więcej [...?] i wazniejsze, lepsze egzemplarze niz na Łysej Górze u $\dot{S} w$. Krzyza..." Cyt. za M.Łodyński: Materiaty do dziejów państwowej polityki bibliotecznej. Wroclaw 1958 s. 58-59, 70

18 J.Wiśniewski: Dekanat miechowski. Radom 1917, s. 129

${ }^{19}$ Por. Kartoteka Prow. BUW. Dla uściślenia należy dodać, że przebadano dotychczas tylko ok. 30\% zasobu XVII-wiecznego, natomiast część XVIII-wieczna pod względem proweniencyjnym nie jest $w$ ogóle badana.

${ }^{20}$ por. przyp. 17

21 Biblioteka powstała w 1825 roku przy założonym przez władze carskie Seminarium Głównym. Na jej księgozbiór złożyły się wybrane z Biblioteki Publicznej przy 
Uniwersytecie Warszawskim dublety, głównie dzieł teologicznych. Zob. B.Wilejszys: Biblioteka Akademii Duchownej Rzymsko-Katolickiej w Warszawie w: Archiwa, Biblioteki i Muzea Kościelne T. 381979 s. 77, M. Sipayłło: Wstęp w: Katalog druków XV i XVIw. w zbiorach BUWW oprac T.Komenderowa. T. 1 Warszawa 1994 s. 20.

${ }^{22}$ Odpowiedź na kwerendę ks. Proboszcza Parafii Grobu Bożego w Miechowie $z$ dnia 16.07.1993 r.

23 J.Zdanowski: Iluminowane rękopisy księgozbiorów kapitularza katedralnego i Seminarium duchownego w Kielcach oraz kosiciota parafialnego w Miechowie. Kielce 1929; Zbiory rękopisów... op. cit. s. 67.

${ }^{24}$ L. Hajdukiewicz: op cit. s. 22-23

${ }^{25}$ L. Hajdukiewicz: op. cit. s. 99. Z tego legatu $w$ zbiorach BUW dotychczas odnaleziono 5 woluminów $\mathrm{z} X \mathrm{XVI} w$. - sygn. Sd. 602.321, 28.2.1.11, 28.3.1.14, 28.13.7.31; $z$ XVII w. - sygn.: 13.9.1.18

${ }^{26} \mathrm{~W}$ Bibliotece Seminarium Archidiecezjalnego w Warszawie odnaleziono jedna książkę $z$ nieznanym dotychczas superekslibrisem Jaskłowskiego, datowanym na rok 1610 (sygn. K. 10.41).

${ }^{27}$ Jako pierwszy występuje Stanisław z Lowicza zmarły w 1540 syn Jana, immatrykulowany w 1511 r., uczeń Jana Sacrana z Oświęcimia i wydawa jego dzieł, pedagog $i$ popularyzator treści humanistycznych $w$ epistolografii, na stanowisku docenta od 1517 r., od 1531 doktor medycyny, prowadził teatr szkolny. Historia Nauki Polskiej. T. 6. oprac. L.Hajdukiewicz. Wrocław 1974 s. 639. Drugim był zmarty ok. 1550, kaznodzieja w kościele św. Anny w Krakowie, $1526 \mathrm{dr}$ teologii, od 1530 proboszcz w Pajęcznie. W.Wisłocki: Incunabula Typographica Bibliothecae Iniversitatis Jagiellonicae. Kraków 1900 s. 294. Tenże: Katalog rękopisów Biblioteki Uniwersytetu Jagiellońskiego. Kraków 1877 z. 1 poz. 1733.

${ }^{28}$ W. Wisłocki: Z przesztości Uniwersyletu Krakowskiego. w: Przeglad Powszechny. 1889 s. 226.

29 por: A Jocher: Obraz hibliograficzno-historyczmy literatury i nauki w Polsce Wilno 1840-1857 T. 2 s. 298, 579 oraz T. 3. s. 61; M.Nowodworski: Encyklopedia Kościelna. Warszawa 1903 T. 21 s. 411; Encyklopedia Powszechna S.Orgelbranda. Warszawa 1864 T. 17 s. 651-652; K.Mecherzyński: Historya wymowy w Polsce. Kraków 1858 T. 2 s. 44-45; M.Wiszniewski: Historya literatury polskiej. Kraków 1857 T. 9 s. $178,205,410$.

${ }^{30} \mathrm{~J}$. Gacki: op. cit. s. 230-231.

${ }^{31}$ P.Pękalski: O poczqtku, rozkrzewieniu i upadku XX Kanoników Stró̇ów' św. Grohu Jerozolimskiego. Kraków 1867 s. 143-144.

${ }^{32}$ M.Bulinski: op. cit. s. 480.

${ }^{33}$ PSB T. 2 Kraków 1936 s. 23

34 H.E.Wyczawski: Stownik polskich teologów katolickich. Warszawa 1981 s. $133-134$.

${ }^{35}$ Encyklopedia Katolicka. Lublin 1976 T. 2 s. 523.

${ }^{36}$ S. Nakielski: op. cit. s. 663-664.

${ }^{37}$ J.Gacki: op. cit. S. 221.

${ }^{38}$ S. Nakielski: op. cit. s. 693

${ }^{39}$ A. Karbowiak: Miechowici a oświcta w: Muzeum R. 221906 T. 2 s. 450

4) por. H.Fros, F. Sowa: Twoje imię. Przewodnik onomastyczno-hagiograficzny. Kraków 1975 s. 130. 
${ }^{41}$ R.Oczykowski: Przechadzka po Lowiczu. Lowicz 1921 s. 24.

${ }^{42}$ M.Witanowski: Obraz nagrobkowy z XVT w. we Wrocieryzu. w: Sprawozdania Komisji do Badania Historii Sztuki w Polsce 1912 s. 399-400, Katalog zabytków sztuki w Polsce. Warszawa 1957. T. III woj kieleckie z. 3, pow. jędrzejowski s. 42-43, fig. 68; J.Wiśniewski: Historyczny opis kosiciolow, miast, zabytków i pamiqtek w Jęurzejowskiem. Marjówka 1930 s. 386

43 J.Lukaszewicz: Historya szkót w Koronie i w Wielkim Księstwie Litewskim. Poznań 1851 T. 3. S. 469; Z. Skiełczyński: Zycie umysłowe $w$ dawnym Łowiczu. Łowicz 1987 s. 2

${ }^{44}$ M.Małuszyński: Handel Łowicza w XV7 wieku. Lowicz 1983 s. 5

45 Stownik Geograficzny... T. 14 Warszawa 1895 s. 151

46 Album Studiosorum Universitatis Cracoviensis. Kraków 1892. T. 2 oprac. A.Chmiel s. 224; Zapisany przez Muczkowskiego w 1512 Stanisl. de Lovycz (conventus Miechoviensis professus) raczej dotyczy innego Stanisława z Lowicza, a mianowicie późniejszego doktora teologii i proboszcza w Pajęcznie (por przyp. 27); J Muczkowski: Statuta nec non Liber promotionum philosophorum ordinis in Universitate studiorum Jagellonica abanno 1402 ad anmum 1849. Cracoviae 1849 s. 154.

${ }^{47}$ S. Nakielski: op. cit. s. 620

${ }^{48}$ J.Muczkowski: op. cit. s. 188

${ }^{49}$ tamże s. 191 .

${ }^{50} \mathrm{~W}$.Wisłocki: Liber diligentiarum facultatis artisticat Universitatis Cracoviensis. P.1 (1487-1563). Kraków 1886 s. 224; H.Barycz: op. cit. s. 417.

${ }^{51}$ P.Pekkalski: op. cit. s. 143

${ }^{52}$ Z.Pęckowski: op. cit. s. 362

${ }^{53}$ Elenchus contentorum in hoc enchiridio. De gloriosae Virginis Mariae Dei Genitricis immaculata conceptione fidelis et catholica assertio. Contiones item tres de eadem conceptione ad populum habitae... adiecta sum quaedam religiosorum (et qui monasticam professi sum vitam) instituta... Cracoviae: ex off. Ungleriana, [po 15 XII] $1538,8^{0} \mathrm{k}$. nlb 42 (ost. cz.), sygn.: a-D8.E10.

${ }^{54} \mathrm{E} 12,430$

55 tamże, 21, 422.

${ }^{56}$ por. T.Wierzbowski: Bibliographia Polonica XV ac XI'T. Varsoviae 1894 poz. 2195; Katalog Biblioteki Horynieckiej xx. Poniniskich. Oprac. A.Kawecka-Gryczowa, K.Piekarski. Cz. 1 Warszawa 1936 poz. 128 odwołuje się do obu cytatów z bibliografii Estreicherów; natomiast Katalog Starych Druków Biblioteki Zakładu Narodowego im. Ossolinskich. Oprac M.Bohonos. Wrocław 1965 poz. 129 ponownie wprowadza opis pod hasło „Beda Venerabilis". Karty katalogowe znajdujące się w Katalogu Centralnym Polonikow XVI wieku prowadzonym przez Bibliotekę Narodową były sporządzone zarówno pod hasłem Beda Venerabilis, jak i [z] Łowicza Stanisław. Obecnie po melioracji wszystkie opisy znajdują się pod hasłem: [z] Łowicza Stanisław.

${ }^{57}$ Index Aureliensis ('atalogus Librorum Sedecimo Seculo Impressorum. Baden Baden 1968 poz. 115.635

${ }^{58}$ Enchiridion R.Stanislai a Lowicz Poloni... De Immaculata conceptione Beatissimae Virginis Mariae propositum. It in Officina Ungleriana Anno Domini 1538. Cracoviac impressum modo vero cura ef studio M.lacobi Pauli Radlinski Poloni... reimpressim. Cracoviae: typ. Mich. Dyaszewski [po I XII] $15478^{\circ}$ k. nlb. 9, s. 173, k. nlb. 2. Zawiera ponadto Bullae summorum pontificum pro Immaculata conceptione 
Sanctissimae Virginis Mariae variis temporibus editae per quas confirmatur Sententia Stanislai a Lowicz... E 21, 423

${ }^{59}$ Cracoviae: in off. Vietoris, 1539. $4^{\circ}$. E 21, 423

${ }^{60}$ De Maria Virgine Deipara, hymnorum libellus... per M.Stanislaum a Lowicz.. Cracoviae: Hier. Vietor impr. 25 VI 1540 [rz.] $8^{0}$ Jocher 3712, E 21, 423.

${ }^{61}$ Res gestae Thomae de Ilkuse Praepositi Generalis. E 21, 423.

${ }^{62}$ S.Nakielski: op. cit. s. 350.

${ }^{6}$ J. Wiśniewski: op. cit. s. 387.

${ }^{64}$ H.Barycz: op.cit. s. 406-408.

${ }^{65}$ J.Wolny: Kaznodziejstwo katedralne w Krakowie na tle srodowiska (okres 15201584) w: Cracovia litterarum pod red. T.Ulewicza. Kraków 1991 s. 306.

${ }^{66}$ tamże, s. 309.

${ }^{67}$ H.Barycz: op. cit. s. 415; J.Zathey, A.Lewicka-Kamińska, L.Hajdukiewicz: $\mathrm{Hi}$ storia Biblioteki Jagiellońskiej. Kraków 1966 T. 1 s. 249.

${ }^{68}$ Kościół pod wezwaniem św. Jana i szpital wybudował w 1243 r., na przedmieściu, książę wielkopolski Przemysław i powierzył opiekę bożogrobcom. Istniał do 1820r.

${ }^{69}$ S.Nakielski: op. cit. s. 600-661

${ }^{70}$ S.Nakielski: op. cit. s. 663-664; P.Pękalski: op. cit. s. 144.

71 J.Korytkowski: Arcybiskupi gnié́nieńscy, prymasowie i metropolici polscy. Poznań 1889 T. 3 s. 273

72 J.Korytkowski: Pralaci i kanonicy katedry metropolitalnej gnieżnieńskiej. Gniezno 1883 T. 2 s. 15; J.Nowacki: Falęcki Stanisłow. PSB T. 6 Kraków 1948 s. 353

${ }^{73}$ Data pierwotnie błędnie odczytana jako 1572 - informacja Kierownika Oddziału Zbiorów Specjalnych Biblioteki PAN w Gdańsku mgr. Anny Siemiginowskiej.

${ }^{74}$ szerzej na ten temat zob.: W. Szelińska: Ksiqzka Erazma z Rotterdamu w srodowisku krakowskim w XVT wieku. Kraków 1990.

${ }^{75}$ K.Piekarski: Ksiqżka w Polsce XV i XVI w. w: Kultura Stropolska. Kraków 1932 s. $352-384$.

${ }^{76}$ M.Sipayłło: Polskie superekslibrisy... op. cit. S. 54, tabl. 11

77 zob. też. M.Jarosławiecka-Gąsiorowska: Ikonografia świecka na oprawach XVI i XVII w. w: Rocznik Biblioteki Narodowej R. 61970 s. 327.

${ }^{78}$ A. Kawecka-Gryczowa: Biblioteka ostatniego Jagiellona. Wrocław 1988 s. 96.

${ }^{79}$ Encyklopedia Wiedzy o Ksiqzice. Wrocław 1971 szp. 1021.

${ }^{80}$ M.Krynicka: Oprawy ksiazkowe z herbami ostatnich Jagiellonów w zbiorach Muzeum Narodowego w: Krakowie w Rozprawy i Sprawozdania Muzeum Narodowego w Krakowie T. 121980 s. 39; A.Kawecka-Gryczowa: op. cit. s. 96.

${ }^{81}$ I. Schunke: Studien zum Bilderschmuck der Deutschen Renaissance-Einbände. Wiesbaden 1959 s. 88-141; zob. też: Katalog starych druków Biblioteki Poznańskiego Towarzystwa Przyjaciót Nauk. Polonica XVI w. Oprac. E.Stelmaszczuk. Poznań 1991 poz. 24.

${ }^{82}$ Podobizny zob.: Katalog druków XV i XVI wieku BUW. op. cit. T. 1 tabl. IV.

83 J.A.Kosiński: Biblioteka konwentu dominikanów w Sieradzu na przetomie XVI i XVII w. w: Studia nad historiq dominikanów w Polsce. Pod. red. J.Kłoczowskiego. T. 2 Warszawa 1975 s. 393-394.

84 A.Kawecka-Gryczowa: Nieznany bihliofil polski XTT wieku Maciej Bech w: Roczniki Biblioteczne R. 211977 z. 1-2 s. 116-140; J.Wiśniewski: Katalog pralatow i kanoników sandomierskich. Radom 1928 s. 19-21

${ }^{85}$ M.Sipayło: Polskie supereksilibris." op cit. s. 6. 